Abstracta Iranica Abstracta Iranica

Revue bibliographique pour le domaine irano-aryen

Volume 23 | 2002

Comptes rendus des publications de $\mathbf{2 0 0 0}$

\title{
Goftegū-hā. Jamšīd 'Alīzāde éd., Tehrān, Negāh, 1379/2000, 280 p. [Entretiens]
}

\section{Christophe Balaÿ}

\section{(2) OpenEdition}

1 Journals

\section{Édition électronique}

URL : http://journals.openedition.org/abstractairanica/35905

DOI : 10.4000/abstractairanica.35905

ISSN : 1961-960X

Éditeur :

CNRS (UMR 7528 Mondes iraniens et indiens), Éditions de l'IFRI

\section{Édition imprimée}

Date de publication : 15 mai 2002

ISSN : 0240-8910

Référence électronique

Christophe Balaÿ, « Goftegū-hā. Jamšīd 'Alīzāde éd., Tehrān, Negāh, 1379/2000, 280 p. [Entretiens] », Abstracta Iranica [En ligne], Volume 23 | 2002, document 328, mis en ligne le 08 février 2010, consulté le 25 septembre 2020. URL : http://journals.openedition.org/abstractairanica/35905; DOI : https:// doi.org/10.4000/abstractairanica.35905

Ce document a été généré automatiquement le 25 septembre 2020.

Tous droits réservés 


\title{
Goftegū-hā. Jamšīd 'Alīzāde éd., Tehrān, Negāh, 1379/2000, 280 p. [Entretiens]
}

\author{
Christophe Balaÿ
}

1 Quatorze entretiens, pour la plupart déjà publiés dans des ouvrages ou des revues dont on trouve toutes les références en fin de volume ainsi qu'un index des noms. Les entretiens s'efforcent de faire le tour de l'œuvre et de la personnalité de ce poète azerbaïdjanais exceptionnel par son bilinguisme turco-persan puisqu'il a produit son œuvre dans les deux langues indifféremment.

INDEX

Thèmes : 11.1.2. Littérature persane moderne

\section{AUTEURS}

\section{CHRISTOPHE BALAŸ}

IFRI - Téhéran 